\title{
INSTITUTE AFFAIRS I AFFAIRES DE L'INSTITUT
}

\section{The Executive Director Reports}

After three years of planning and organizing, our Annual General Meeting and Convention came to an end on October 7, with the return of the delegates from the technical field workshops. My many thanks to all our members in Alberta that were involved in the planning of this convention, from being chiefs, to stream captains, to leading companion tours. We had over 1,500 people, including over

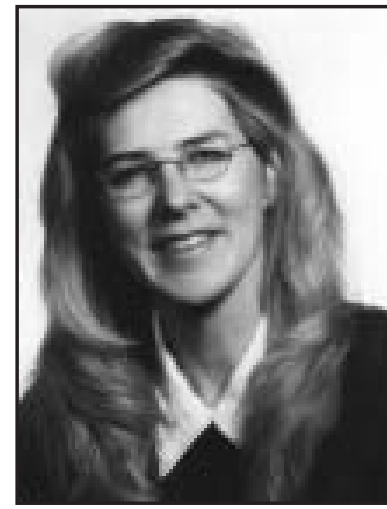

Roxanne Comeau R.P.F. Executive Director 250 students, attend the convention from Canada and United States, with over 150 speakers and 10 technical field workshops. The joint convention with the Society of American Foresters, lead by co-chairs Brydon Ward and Fred Ebel was one for the history books for the Institute. The Institute thanks all its members, sponsors, exhibitors and on-site volunteers for all their support, and in showcasing Canada.

Our National Board of Directors and Executive Committee met for a day and half prior to the start of the convention. The priorities that were identified by the National Board can be summed up under the banner "Facilitating Communications and Outreach to Maintain Institute Health." A framework for action was prepared and is provided below:

\section{Facilitating communication and outreach - Strategic Direction Five}

We will increase the capacity and effectiveness of the Institute to inform our membership and others about Canadian forestry issues and practices through actions such as:

- continuing to provide The Forestry Chronicle in a format suitable to the membership

- ensuring that the themes, format and content of The Forestry Chronicle are relevant to the membership

- facilitating the establishment of active theme-specific working groups
Canadian Institute of Forestry/

Institut forestier du Canada

Suite 606, 151 Slater St.

Ottawa, Ontario, Canada K1P 5H3

Tel./Tél: (613) 234-2242

Fax/Téléc: (613) 234-6181

E-mail/courrier électronique: cif@cif-ifc.org

Website/site Internet: $w$ ww.cif-ifc.org

President/Président - Michael McLaughlan

$1^{\text {st }}$ Vice-President $/ 1^{\text {er }}$ vice-président - Chris Lee, R.P.F.

$2^{\text {nd }}$ Vice-President/2 $2^{\text {ème }}$ vice-président - Doug Staples, R.P.F

Past President/Président sortant - Richard L. Macnaughton, R.P.F

Executive Director/directrice executive - R. Comeau, R.P.F

\begin{tabular}{|c|c|c|}
\hline Sections & $\begin{array}{l}\text { Directors/ } \\
\text { directeurs }\end{array}$ & $\begin{array}{l}\text { Section Chairs/ } \\
\text { président de } \\
\text { section }\end{array}$ \\
\hline Algonquin & Don Willis & Allan Stinson \\
\hline Cariboo & Ed Morrice & - \\
\hline Cariboo Chilcotin & Keith Dufresne & - \\
\hline Central Ontario & Peter Newton & Robert Currell \\
\hline Champlain & - & - \\
\hline Klondike & Susan Skaalid & Gregory Cowman \\
\hline Lake of the Woods & Charles Queau & - \\
\hline Manitoba & Julie Ringash & Trevor Stanley \\
\hline Maritime & Doug Prosser & Daniel Rogers \\
\hline Newfoundland & Wayne Kelly & - \\
\hline Northern Ontario & Wally Bidwell & Nikki Wood \\
\hline \multicolumn{3}{|l|}{ Northwestern } \\
\hline Ontario & Don Nixon & Avery Dorland \\
\hline Nova Scotia & Mac Barkhouse & - \\
\hline Okanagan & Rod Willis & - \\
\hline Orleans & Robert Beauregard & Evelyne Thiffault \\
\hline Ottawa Valley & Jeff Young & Tony Bull \\
\hline Pacific & - & - \\
\hline Rocky Mountain & Todd Nash & Geoff Clarke \\
\hline Saskatchewan & Darryl Sande & - \\
\hline Skeena & - & - \\
\hline Southern Ontario & Bruce Ferguson & - \\
\hline Vancouver & Mike Prueter & - \\
\hline Vancouver Island & Charlie Klasen & Brian Titus \\
\hline
\end{tabular}

- updating the Canadian forestry practices web information

- continuing to develop and update policy and position papers - a compendium will be distributed to the membership early in 2005

- ensuring section participation and dialogue in the development and implementation of Institute affairs

\section{Strategic Direction Four - Maintaining Institute Health}

We will ensure that the Institute remains relevant to the current and future membership through actions such as:

- increasing the profile of the organization to potential members 


\section{Rapports de la directrice exécutive}

Après trois années de planification et d'organisation, notre assemblée générale annuelle et notre congrès se sont terminés le 7 octobre, avec le retour des délégués qui avaient participé aux ateliers techniques sur le terrain. Mes sincères remerciements à tous nos membres de l'Alberta qui ont participé à la planification de ce congrès, des capitaines d'équipes jusqu'aux accompagnateurs des excursions pour les invités. Nous avons accueilli plus de 1500 personnes dont 250 étudiants au congrès, en provenance du Canada et des États-Unis, ainsi que plus de 150 conférenciers et dix ateliers techniques sur le terrain. Ce congrès conjoint avec la Society of American Foresters, présidé par Brydon Ward et Fred Ebel a marqué l'histoire de l'Institut. L'Institut remercie tous ses membres, les commanditaires, les exposants et les bénévoles pour leur appui et pour cette image du Canada.

Notre conseil national d'administration et notre comité exécutif se sont réunis pendant une journée et demie avant le début du congrès. Les priorités qui ont été identifiées par le conseil national peuvent être résumées sous le thème « Faciliter les communications et nos approches pour maintenir la vitalité de l'Institut ». Un cadre de travail pour la suite des événements a été élaboré et est présenté ci-après :

\section{Faciliter les communications et nos approches - Cinquième orientation stratégique}

Nous accroîtrons la capacité et l'efficacité de l'Institut en matière d'information de nos membres et du public sur les enjeux forestiers et les pratiques de foresterie au Canada par l'entremise de :

- la poursuite de la diffusion du Forestry Chronicle dans un format approprié pour nos membres

- la vérification que les thèmes, le format et le contenu du Forestry Chronicle sont pertinents pour les membres

- en facilitant la mise en place de groupes de travail actifs selon les thèmes retenus

- la mise à jour de l'information disponible sur les pratiques forestières sur le site Internet

- la poursuite du développement et de la mise à jour des politiques et des documents d'orientation - un compendium sera distribué aux membres au début de 2005

- la sollicitation de la participation et des échanges avec les sections dans le développement et l'implantation des affaires de l'Institut

\section{Quatrième orientation stratégique - Maintien de la vitalité de l'Institut}

Nous nous assurerons que l'Institut demeure pertinent aux yeux des membres actuels et à venir par l'entremise de :

- l'accroissement du profil de l'organisation auprès de membres potentiels

- l'identification des méthodes permettant l'amélioration de la structure des comités de l'organisation (par ex., rajeunissement des sections, le comité des sciences et technologies forestières)

- la considération des besoins et des préférences des membres dans le domaine de la livraison du programme (par ex., Le Forestry Chronicle, le site Internet)

- du maintien d'une situation financière responsable et viable

\section{Canadian Institute of Forestry/Institut forestier du Canada}

The Canadian Institute of Forestry/ Institut forestier du Canada (CIF/IFC) has been the national voice for forestry professionals since 1908. Our membership includes foresters, forest technologists and technicians, educators, scientists and others with a professional interest in forestry. We work in government, industry, research, education and consulting and represent one of the largest professional voices for forestry in Canada.

\section{Our Mission}

The Mission of the CIF/IFC is to advance the stewardship of Canada's forest resources, provide national leadership in forestry, promote competence among forestry professionals, and foster public awareness of Canadian and international forestry issues.

\section{Our Values and Beliefs}

We believe that members of the Canadian Institute of Forestry/ Institut forestier du Canada (CIF/IFC) should have an intimate knowledge and understanding of Canada's forests.

We believe that the stewardship of our forests must be based on an understanding of ecological principles coupled with appropriate inventory and monitoring to ensure that the criteria of ecological integrity and function are maintained within an acceptable sociological framework.

Through this understanding, members should promote the intelligent use of Canada's forests to provide a sustainable flow of a wide range of forest commodities, representing a balance of economic, spiritual, recreational and wildlife habitat values.

A wide range of forest alternatives is possible, ranging from natural forests to intensively managed tree farms. We believe that the mix of forest uses required to satisfy Canadian needs should be based on an informed public dialogue. Our members should play a constructive role in facilitating such debate. 
- identifying methods to improve the structure of the organization committees (e.g., section rejuvenation, Forest Science and Technology Board.

- reflecting membership needs and preferences in area of program delivery (e.g., The Forestry Chronicle, website)

- maintenance of an accountable and viable financial situation

- encouraging a healthy base of valued volunteers to support Institute activities.

Our vision for 2004-2005 is to be prominent proactive voice - representing forest practitioners at local, regional, and national levels. A media response kit is being developed for the sections, and issues will be identified over the next few months. We would encourage all our members to become active in the sections, and assist in informing others about forestry issues and Canadian forestry practices.

Please visit our website www.cif-ifc.org for more information.
- du support d'une saine équipe de bénévoles compétents pour appuyer les activités de l'Institut

Notre vision pour 2004-2005 est d'être un porteparole déterminant et proactif - représentant les professionnels de la foresterie au niveau local, régional et national. Une trousse de réponse aux médias est en voie d'élaboration pour les sections et les enjeux seront identifiés au cours des prochains mois. Nous encourageons tous nos membres à s'impliquer au niveau de leur section et aider à informer ceux qui nous entourent sur les enjeux forestiers et les pratiques forestières au Canada.

Veuillez consulter notre site Internet www.cif-ifc.org pour plus d'information.

Roxanne Comeau, R.P.F.

Directrice exécutive

20 octobre 2004

Roxanne Comeau, R.P.F.

Executive Director

October 20, 2004

\section{Thank You to our Corporate Sustaining Members}

\author{
Abitibi-Consolidated Corporation \\ Alberta Sustainable Resource Development \\ Aldata Software Management Inc. \\ Bowater Inc. \\ Canadian Forest Service NRCan \\ Canfor Corp. \\ Corporation City Sault Ste. Marie \\ Daishowa-Marubeni Int. Ltd - Peace River Divsion \\ Dept. of Forest Resources and Agrifoods \\ Domtar Inc. \\ Faculty of Forestry \& The Forest Environment \\ FERIC \\ FPAC \\ Fraser Papers Inc. \\ Grant Forest Products Inc. \\ Groupe de Recherche Ecologie Forestiere \\ IMFNS/IDRC \\ Industry Relations Group OMNR \\ J.D. Irving Limited - Woodlands Division \\ Jiffy Products (N.B.) Ltd. \\ KPMG LLP \\ La Foret modele du Bas-Saint-Laurent
}

\author{
Logging And Sawmilling Journal \\ Louisiana Pacific Canada Ltd. \\ Newfoundland \& Labrador Lumber Producers Association \\ Ontario Ministry of Nat Resources \\ Ontario Ministry of the Environment \\ PEI Department of Agriculture \& Forestry \\ Riverside Forest Products Limited \\ St.Anne-Nackawic Pulp Co Ltd - Woodlands \\ Stora Enso Port Hawkesbury Ltd. \\ Tembec Industries Inc. \\ Tembec Industries Inc. \\ Timberline \\ Tolko Industries Ltd. \\ Town of Hinton \\ Transenergie \\ UNBC Forestry Program \\ University of N.B. Faculty of Forestry - Sci Lab \\ Universite de Moncton \\ University of British Columbia \\ University of Toronto \\ West Fraser Mills Ltd. \\ Weyerhaeuser Canada Ltd.
}

\section{Thank You to our Individual Sustaining Members}

Harvey William Anderson

Arthur Bickerstaff

George Brown

Brian Cardwell

James H. Cayford

G. Wilfred I. Creighton

Eric C. Crossin

C. Harry Gairns

\author{
Dr Joseph Gardner, CM \\ George J. Garner \\ W. Ross Grinnell \\ Ronald Dean Hallett \\ Erik Jorgensen \\ Alfred Kabzems \\ Nenad Kontic \\ Don Lockhart
}

\author{
James D. MacArthur \\ J. K. Naysmith \\ Vidar J. Nordin \\ Hugh A. Peacock \\ I. Cameron M. Place \\ Douglas R. Redmond \\ François Sauvageau \\ John T. Somerville
}

\author{
Robert G. Steele \\ Roy F. Sutton \\ Barry Volkers \\ Arden Whidden \\ David A. Wilson \\ John C. Wright \\ A.( Dolf) Wynia
}

